\title{
Macrofouling in unidirectional flow: miniature pipes as experimental models for studying the interaction of flow and surface characteristics on the attachment of barnacle, bryozoan and polychaete larvae
}

\author{
Pei-Yuan Qian ${ }^{1, *}$, D. Rittschof ${ }^{2}$, B. Sreedhar \\ ${ }^{1}$ Biology Department, Hong Kong University of Science and Technology, Clear Water Bay, Hong Kong \\ ${ }^{2}$ Duke University Nicholas School of the Environment Marine Laboratory and Zoology Department, \\ 135 Duke Marine Lab Road, Beaufort, North Carolina 28516-9721, USA
}

\begin{abstract}
Tubes constructed of different materials were used to examine the role of hydrodynamics and surface characteristics, as measured by contact angles, on larval attachment of marine polychaetes, bryozoans and barnacles. Tubes (10 mm inner diameter) of 7 different materials, ranging in contact angle from $25^{\circ}$ to $113^{\circ}$, were used. Laboratory and field experiments were conducted using a range of flow rates from 1.7 to $84.9 \mathrm{~cm} \mathrm{~s}^{-1}$. For all 3 taxa of organisms, the results of field experiments were similar to those of the laboratory experiments. Larval settlement of the polychaete Hydroides elegans and the bryozoan Bugula neritina was the highest at a flow rate of $\leq 2.1 \mathrm{~cm} \mathrm{~s}^{-1}$, and decreased when the flow rate was increased. $H$. elegans larvae settled within the narrowest range of flow rates $\left(1.7\right.$ to $\left.9.1 \mathrm{~cm} \mathrm{~s}^{-1}\right), B$. neritina larvae settled over the widest range of flow rates $\left(1.7\right.$ to $\left.53.0 \mathrm{~cm} \mathrm{~s}^{-1}\right)$, and barnacle larvae (Balanus spp.) settled in an intermediate range of flow rates (4.2 to $21.2 \mathrm{~cm} \mathrm{~s}^{-1}$ ). Barnacle larvae did not settle when the flow rate was $<2.1$ or $>21.2 \mathrm{~cm} \mathrm{~s}^{-1}$, and the highest settlement was recorded at the flow rate of $10.6 \mathrm{~cm} \mathrm{~s}^{-1}$. Barnacle larvae showed the highest settlement in glass tubes (smallest contact angle) and the lowest in Teflon tubes (largest contact angle), while $B$. neritina showed the highest larval settlement in Teflon tubes and the lowest settlement in glass tubes. $H$. elegans also showed the highest larval settlement in Teflon tubes, but the lowest settlement in polyurethane and polyethylene tubes. Biofilm formation changed the contact angles of all the tubes, the degree of change varied among the 7 types of tubes. Bacterial densities of biofilm on the 7 types of tubes were significantly different and were not correlated with the initial contact angles of tubes. The bacterial densities on the Teflon tubes were the same as on glass tubes. Our results suggest a very complex interaction among substratum characteristics, flow rates, and larval settlement behavior and indicate the necessity for considering the interaction when one interprets laboratory bioassay data on larval settlement of marine invertebrates.
\end{abstract}

KEY WORDS: Fouling · Hydrodynamics · Barnacles · Bryozoans · Tubeworms · Contact angle · Flow rate Resale or republication not permitted without written consent of the publisher

\section{INTRODUCTION}

The settlement patterns of macrofoulers in a unidirectional flow system, such as seawater intake pipes, should be determined by larval availability, flow

*E-mail: boqianpy@ust.hk dynamics, and physiochemical properties of the pipes. The latter strongly influences biological settlement (Rittschof \& Costlow 1989a,b, Roberts et al. 1991) and adhesion and hence biofouling (Baier 1973, 1982, Burchard et al. 1991). Surface energy, a physiochemical property of all surfaces, has clear effects on larval settlement (review of Crisp 1984, Rittschof et al. 1998). 
Biofilms also directly affect the settlement of a variety of macrofouling larvae, such as barnacles, bryozoans and polychaetes (Crisp 1984, Maki et al. 1988, Holmström et al. 1992, Hadfield et al. 1994, Lau \& Qian 1997, Olivier et al. 2000). Different substrata often support very different fouling communities, depending upon the time and duration of immersion (Becker \& Wahl 1991, Holm et al. 1997).

Surface energy can be understood in terms of the way that fluids spread on a surface. A surface upon which water beads has low free surface energy. A surface with low free surface energy has a low wettability and is hydrophobic; organic solvents spread rather than bead on a surface with low surface energy. Examples of low surface energy surfaces are Teflon and most plastics. On the other hand, water spreads on a surface with high surface free energy. By definition, surfaces with high surface free energy are wettable and hydrophilic. Surface wettability is quantified by contact angle (the angle of a bead of fluid on a surface; Young 1805) by numerous liquids other than water and is correlated with the formation and adhesion of microbial biofilms (Baier 1973, Vrolijk et al. 1990). A surface with high surface energy has a small contact angle, while one with low surface energy has a large contact angle. When contact angles of a surface are measured with organic solvents, they are recorded as the contact angles under non-polar conditions; when measured with pure water, they are recorded as the values under polar conditions.

In seawater, surface energy is temporally variable. Interaction of molecules in the water with the surface changes the surface energy (Meyer et al. 1988, Rittschof \& Costlow 1989b). Ultimately, the biological effect of surface properties on fouling depends upon a complex suite of variables that include time of year, availability of propagules in the water column, and predation (Roberts et al. 1991, Walters 1992a,b, Holm et al. 1997).

Furthermore, larval settlement in response to different cues is under the influence of many other parameters, including boundary layer flows (Butman 1986, 1987, Wethey 1986, Pawlik et al. 1991, Walters 1992a,b, Mullineaux \& Garland 1993, Walters et al. 1997), chemical cues from the environment, molecular and bacterial films, and substratum conditioning (Kirchman et al. 1982a,b, Crisp 1984, Wethey 1986, Eckman et al. 1990, Pawlik 1992, Walters 1992a,b, Hadfield et al. 1994, Bryan et al. 1997, 1998, Lau \& Qian 1997, Beckmann et al. 1999, Harder \& Qian 1999). For instance, previous studies have documented the settlement responses to surface energy by Balanus spp. and Bugula neritina ( 2 of the 3 groups that are the topic of this report) in a single flow (Rittschof \& Costlow 1989a), in the absence of flow (Gerhart et al. 1992), as well as in the field in highly variable and undefined flows (Rittschof \& Costlow 1989b, Roberts et al. 1991). Both groups show a clear relationship between substratum surface energy and settlement. Balanus spp. settle preferentially on high surface energy surfaces such as glass, while $B$. neritina settle in highest proportion on low surface energy surfaces such as fluorocarbons and polystyrene. Different surface energies can be generated which physically trap the larvae that contact them (Rittschof \& Costlow 1989a, Gerhart et al. 1992). There are no reports of settlement responses of Hydroides elegans to surface energy.

There have been many experiments examining settlement behavior in the field, which have all, one way or another, tested for habitat selection in response to surface properties under natural flow conditions (e.g. Walters 1992a,b, Qian et al. 1999). In most field studies it is difficult to determine whether surface characteristics, flow, or a combination of the two are responsible for the observed settlement and recruitment patterns.

The objective of the present study was to determine the influence of hydrodynamics and surface properties of the substratum on larval attachment in pipes by 3 cosmopolitan fouling organisms: the tube-building polychaete Hydroides elegans (Haswell), the bryozoan Bugula neritina (L) and the barnacle Balanus amphitrite Darwin. We hypothesized that larval settlement is in response to surface characteristics, regardless of the flow rates being exposed. To test this hypothesis, both laboratory and field experiments for larval settlement of the 3 groups of foulers were conducted with tubes of different materials (with different contact angles), and were subjected to a wide range of flow rates.

\section{MATERIALS AND METHODS}

Studies were conducted in the laboratory with cultured larvae of Hydroides elegans and Balanus amphitrite, as well as brooded larvae of Bugula neritina that were released from adults that had been collected from the field. Field studies were carried out during times when competent larvae were available in the water column. In the field, $H$. elegans and B. neritina could be identified unequivocally, while balanoid barnacles could only be identified to genus.

The life histories and settlement biology of larvae of these 3 species have been well documented (see references listed in Qian et al. 1999).

Larval cultures for laboratory experiments. Hydroides elegans: Polychaete Hydroides elegans larvae were obtained as a laboratory culture by following the methods described in Bryan et al. (1997). Briefly, adult $H$. elegans were obtained from glass panels that were submerged at a fish farm in Port Shelter, near the Hong 
Kong University of Science and Technology (HKUST), or from a laboratory broodstock. Adult worms were placed individually in Petri dishes containing filtered seawater (FSW), and their tubes were gently broken to induce the release of eggs and sperm. Eggs of several females were combined in 1 dish, and were treated with a diluted sperm suspension collected from 2 to 3 males. Eggs were exposed to the sperm suspension for 15 min, then carefully washed twice with FSW to remove excess sperm and transferred to a 41 Nalgene beaker containing FSW. Since a fertilization rate of $>95 \%$ can be easily achieved over a wide range of sperm concentrations (Pechenik \& Qian 1998), sperm concentration was not monitored in the present study. Larvae were fed daily and maintained, following the method of Qiu \& Qian (1997a). Larval competence to settle and metamorphose was assessed by exposing the larvae to a solution of $10^{-4} \mathrm{M}$ isobutyl methylxanthine (IBMX), following the method of Qian \& Pechenik (1998). Competent larvae attached within 1 to $2 \mathrm{~h}$ and metamorphosed within $12 \mathrm{~h}$. All settlement experiments were performed with 5- to 6-d-old larvae, as counted from the time of fertilization.

Bugula neritina: Bryozoan Bugula neritina larvae were released from brooding adults in response to a light shock (Rittschof et al. 1988). Adult colonies utilized were collected from ropes hanging from a floating dock in a fish farm near HKUST. In the laboratory, these colonies were placed in a beaker containing aerated seawater and kept in the dark overnight. The next morning, colonies were transferred to a beaker containing FSW and placed directly under an artificial light. Adults released larvae in response to this light shock. Larvae were then attracted to another light source and within 10 min were pipetted into a clean container of FSW for use in settlement experiments. Feeding was not necessary as $B$. neritina larvae are lecithotrophic and settle within 2 to $3 \mathrm{~h}$ after being released (Bryan et al. 1998).

Balanus amphitrite: Barnacle larvae were cultured by a modification of the procedures of Rittschof et al. (1984). Broodstocks were collected from an intertidal mud flat in Marina Cove $\left(22^{\circ} 19^{\prime} \mathrm{N}, 114^{\circ} 16^{\prime} \mathrm{E}\right)$, Hong Kong. These stocks were kept in the laboratory in aerated seawater. Newly hatched Artemia sp. were offered daily as food. The water was changed, and a light shock was used to induce release of nauplius larvae (Rittschof et al. 1984, Qiu \& Qian 1997b). Nauplius I or II larvae were then attracted to a light source and transferred to a $4 \mathrm{l}$ culture container using a pipette. These nauplii were separated into 11 beakers containing FSW and kept at $28^{\circ} \mathrm{C}$. Planktotrophic Nauplius II larvae were fed with the diatom Skeletonema costatum, maintained, and examined for the presence of cyprids after $4 \mathrm{~d}$, following the method of Qiu \& Qian (1997b). Cyprids were separated from late-stage nauplii by filtration through 250 and $125 \mu \mathrm{m}$ mesh. Cyprids retained by the $125 \mu \mathrm{m}$ mesh were stored at $6^{\circ} \mathrm{C}$ in FSW. Cyprids stored in this way were inactive and did not settle on the container. Three-day-old cyprids were used in the experiments, as storage for $3 \mathrm{~d}$ leads to predictable larval settling rates (Rittschof et al. 1984) and has been used in many previous studies (Maki et al. 1988, 1989, 1990, 1992, 1994, Qiu \& Qian 1997b, Qiu et al. 1997).

Experimental setup. Both laboratory and field experiments were conducted according to the methods described by Qian et al. (1999), with minor modifications. In the laboratory, we used a seawater flow system consisting of 3 tanks: (1) a head tank (4 l), (2) a side tank (6 l) and (3) a bottom tank (6 l) (see Fig. 1 in Qian et al. 1999). A submersible pump moved water from the bottom tank to the side tank. A second pump, in the side tank, moved seawater to the head tank where the water level (and pressure) was constant throughout the experiments.

Tubes were connected to run from the bottom of the head tank into the bottom tank. For each larval species, various flow rates were established within the tubes. There were 3 replicates of each type of tube for each flow rate. The flow rate in each tube was regulated with an adjustable valve placed at the discharge end of the tube and measured with a volumetric cylinder at the outlet to the nearest $0.1 \mathrm{~cm} \mathrm{~s}^{-1}$. After adjusting the flow rate, competent larvae were released into the side tank. The initial larval concentration in the system was 1 larva $\mathrm{ml}^{-1}$. The larvae that did not settle on the tubes were collected in a nylon mesh cup $(90 \mu \mathrm{m}) \mathrm{kept}$ at the outlet of each tube. The percentage of larval population in the system that entered the tubes during the experiment varied with flow rates.

After conducting the experiments with competent larvae of the 3 different species, tubes were removed from the head tank (after $12 \mathrm{~h}$ for the barnacles Balanus amphitrite and Balanus spp. and for Hydroides elegans, and $1 \mathrm{~h}$ for Bugula neritina larvae), filled with FSW and sealed at both ends, and settled larvae were enumerated with a dissecting microscope. The percentage of larval settlement was calculated as the ratio of the number of settled larvae to the number of larvae that were collected in the nylon mesh cup plus the settled larvae.

Seven types of tubes (all with $10 \mathrm{~mm}$ internal diameter) were used: PVC1 (Tygon brand), PVC2 (Nalgene brand), PVC3 (Nalg-nuc.), polyethylene (PE), polyurethane (PU) (Usure brand), Teflon (Nalg-nuc.) and glass (TMS brand). All the tubes were $2 \mathrm{~m}$ long, except the glass tubes, which were $30 \mathrm{~cm}$ long.

For observing the settlement of Hydroides elegans larvae in the laboratory, tubes were pre-soaked in sea- 
water for $48 \mathrm{~h}$ to allow the development of a biofilm on the tube walls. For larval settlement of Bugula neritina and Balanus amphitrite, the experiments were conducted in clean tubes. Previous studies showed that $H$. elegans larvae do not settle on unfilmed surfaces (Bryan et al. 1997, 1998, Lau \& Qian 1997, Harder \& Qian 1999).

Field experiments were conducted for $3 \mathrm{~d}$ on both Balanus spp. and Bugula neritina, and for $5 \mathrm{~d}$ on Hydroides elegans at a fish farm in Port Shelter near HKUST. A submersible pump supplied seawater to the tubes from a depth of $1 \mathrm{~m}$ (see Fig. 2 in Qian et al. 1999). The tubes were connected to the pump by a connector, and the same 7 types of tubes used for the laboratory experiments were employed here. Tubes were suspended horizontally from a floating raft, and aligned parallel in a single row in total darkness by fitting all the tubes in larger, black rubber tubes. The flow rate through each tube was regulated with adjustable valves at both ends of the tubes. Flow rates were checked daily by volumetric measurement at the outlet. During the experiments, the temperature and salinity of the seawater were measured daily with a thermometer and a portable refractometer (ATAGO S/Mill). Experiments were conducted during a period in which hydrobiological conditions at experimental sites were relatively stable, in order to avoid fluctuations in salinity and temperature that might affect the settlement rates of the larvae. After each deployment, tubes were removed from the experimental apparatus, and the settled larvae were enumerated under a dissecting microscope as described for the laboratory experiments. Since a fine mesh is required to collect unsettled larvae of all 3 species, but meshes were rapidly clogged in the field, we attempted to estimate the number of larvae passing through the tubes by quantifying larval density in the water column. Each day over the course of the experiments, 201 of seawater was pumped from the experiment site with a submersible pump. The numbers of Balanus spp. cyprids and larvae of $H$. elegans and $B$. neritina were quantified for each sample. The average larval density in the water column over the experimental period was used to calculate the estimated total number of larvae going through the tube. This technique worked best for barnacle larvae. Larvae of $B$. neritina settled in the sampling apparatus and containers before we could count them. Estimates of $H$. elegans were very low; these larvae may be patchy in time or space. Thus, we could not determine the number of $H$. elegans and $B$. neritina larvae that settled in the tubes as a percentage. For these species, we report only the raw total number of larvae that settled in the tubes under different flows.

Surface preparation for contact angle measurement. Because the tubes were curved, it was difficult to measure the contact angle of the tube surfaces. Thin flat surfaces were required to make accurate measurements. To this end, the tubes of each type were first cleaned and washed in deionized distilled water, cut open, and cut into small pieces. These pieces were dried overnight before being pressed in a PHI compression press (Model SQ230C-XL-3A-21). The samples were pressed at different temperatures (according to their melting points), and held under pressure for 5 to $10 \mathrm{~min}$ before the heaters were switched off, then cooled at a rate of about $2^{\circ} \mathrm{C} \mathrm{min}{ }^{-1}$, which is the natural cooling rate of the press. This limited heat treatment does not change the molecular structure of polymers (Li pers. comm.). To ensure that the sample surfaces were not affected by the surfaces of the press, tube samples were pressed between aluminum foil without using a mold-release agent. The samples were removed from the mold with care, avoiding contamination of their surfaces, and then stored under ambient conditions before contact angle measurement. Contact angles for both unfilmed and filmed tubes were based on flat pieces, and all of the tubes were treated in the same way. Our results are comparable to the contact angle readings of glass tubes found in earlier studies (Rittschof \& Costlow 1989b), indicating that the flattening treatment did not affect contact angle measurement very much. Contact angles of each test substratum were measured with a KRUSS contact angle measuring instrument.

Water (HPLC Grade) and methylene iodide were used as test liquids for measuring the contact angle of the test substratum under polar and non-polar conditions respectively. A micromatic syringe was used to place test liquid on the sample surfaces. One drop of the test liquid was placed onto the sample surface. Contact angles were measured using volume control of the sample drops at room temperature (between 18 and $21^{\circ} \mathrm{C}$ ). Five small pieces for each type of tube material were used to measure both the receding and advancing angles of each drop of testing liquid. The data for the receding and advancing angles were averaged to give the contact angle of each tube material.

To examine the effect of biofilm on the contact angles, natural seawater was pumped through the tubes to allow the development of biofilm on their inner walls. After $48 \mathrm{~h}$, the tubes were disconnected from the pump system, and a small section of each tube (about $20 \mathrm{~cm}$ from the opening) was prepared for contact angle measurement following the method described above. Heating and pressing the tubes may affect the surface characteristics of the biofilm. Therefore, we only want to examine the general trend of changes in contact angles of filmed, when compared with unfilmed, surfaces. We found that the changes followed the general trend (Gerhart et al. 1992), except 
for glass tubes, which appeared to be due to the effect of the high temperature required for flattening the tube. Heating glass to $500^{\circ} \mathrm{C}$ results in very high surface energy (Baier 1984). In the case of the lower-temperature-treated surfaces, our results should provide trends and are reported with these experimental limitations in mind.

To determine the relationship between bacterial density and the contact angles of different types of tubes, bacteria attached to the inner walls of tubes after $48 \mathrm{~h}$ were stained with DAPI, and their densities were determined under light microscopy at 1000x magnification (Turley 1993). The numbers of bacterial cells under 10 microscopic fields were enumerated using 5 tubes for each tube type.

Data analyses. All the statistical analyses were based on un-transformed data. Whenever the data set did not meet the normality assumptions of parametric

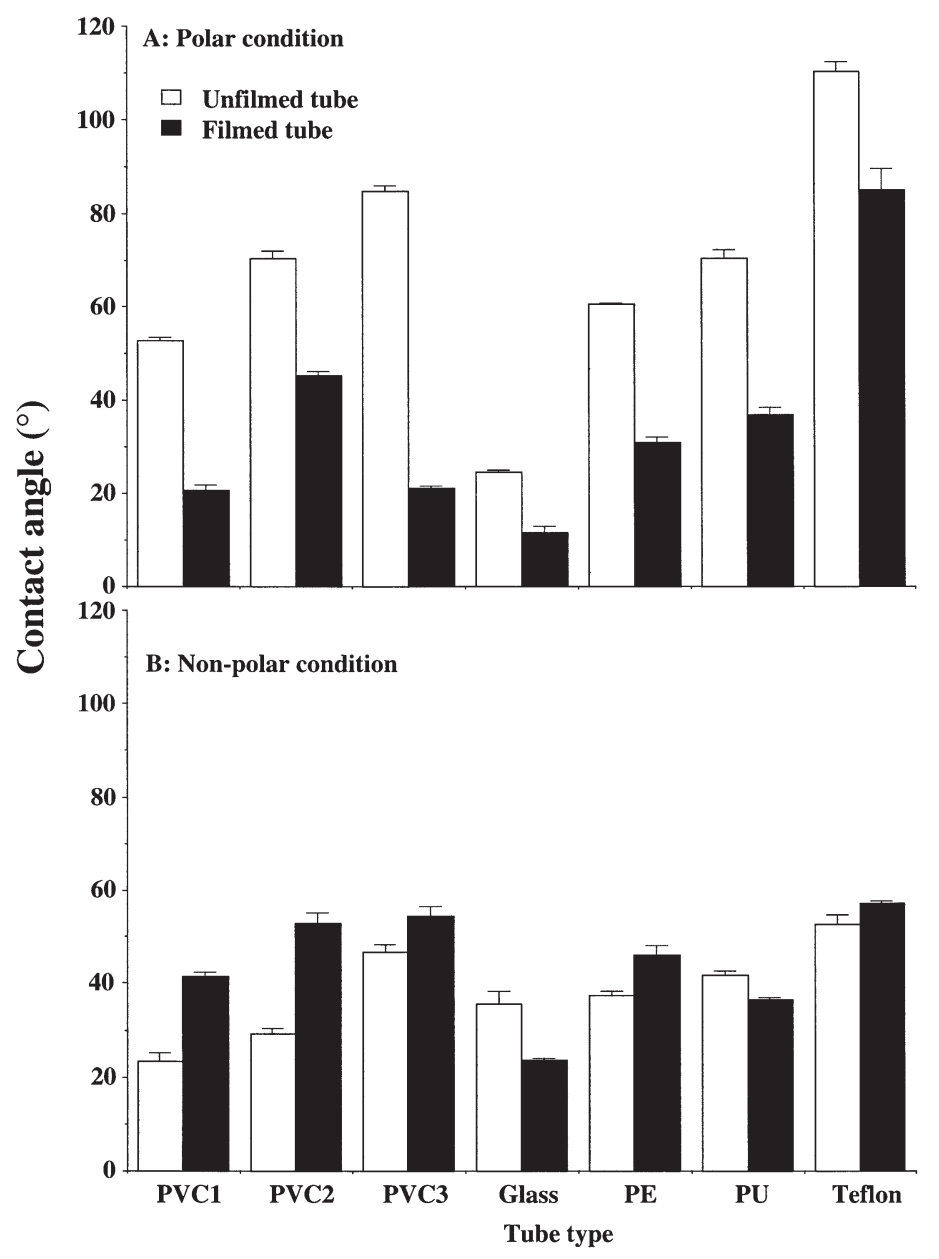

Fig. 1. Contact angle measurements of 7 types of tubes: (A) contact angles measured in polar conditions; (B) contact angles measured in non-polar conditions (open bars: unfilmed tubes; solid bars: tubes with 48-h-old natural biofilm) analysis (Shapiro \& Wilk test, Zar 1999), non-parametric ANOVA (Kruskal-Wallis) and non-parametric multiple comparison tests were used. Other data sets were analyzed by parametric ANOVAs (1-way or 2-way) and Tukey- $B$ multiple comparison tests (Zar 1999). Specifically, 2-way ANOVA was used to test the effects of tube materials and biofilm on contact angles of 7 types of tubes under polar or non-polar conditions respectively. Due to strong interaction between tube materials and biofilm effect, 1-way ANOVA and Tukey- $B$ multiple comparison tests were used to rank the tube types based on their contact angles for nonfilmed tubes under either polar or non-polar conditions, as well as for filmed tubes under both conditions. The Kruskal-Wallis test and non-parametric multiple comparison test were used to test the effect of the tube type on larval settlement at each given flow rate. Nonparametric Spearman's rank correlation coefficient test was used to explore the relationship between contact angles and larval settlement at any given flow rate for each species in either laboratory or field experiments (either percentage or in number of larvae settled) (Zar 1999). The effect of the tube type on bacterial density on the inner walls of tubes was assessed using 1-way ANOVA followed by a Tukey- $B$ multiple comparison test (SPSS package, Version 4.0).

\section{RESULTS}

\section{Contact angle of 7 types of tubes}

Materials for constructing tubes (tube type), and biofilm on the tubes, significantly affected the contact angles of tubes measured under either polar or non-polar conditions (Fig. 1, Table 1). However, there were also strong interactions between tube types and biofilm effects. Therefore, 1-way ANOVAs and Tukey- $B$ multiple comparison tests were used to rank the 7 types of tubes (filmed or unfilmed) under polar or non-polar conditions respectively. When the tubes were unfilmed, the contact angles of the 7 types of tubes could be arranged as follows: for polar conditions, Teflon $>$ PVC 3 $>\mathrm{PU}=\mathrm{PVC} 2>\mathrm{PE}>\mathrm{PVC} 1>$ Glass (1-way ANOVA, $F_{6,34}=425.6, \mathrm{p}<0.0001$ ); for nonpolar conditions, Teflon $>$ PVC $3>\mathrm{PU}>\mathrm{PE}=$ Glass $>$ PVC2 $>$ PVC 1 (1-way ANOVA, $F_{6,34}=$ 52.1, p < 0.0001) (Fig. 1). When the tubes were filmed, the contact angles changed substantially. For the polar conditions, the contact angles of the filmed tubes decreased, with the largest decrease being found in PVC3 (>74\% 
Table 1. Summary of 2-way ANOVA results on effects of biofilm and types of tubes on contact angles of tubes

\begin{tabular}{|lrrrc|}
\hline Factor(s) & df & SS & $F$ & $p$ \\
\hline Polar & & & & \\
Filmed/non-filmed (A) & 1 & 7037 & 1240 & $<0.0001$ \\
Tube type (B) & 6 & 14116 & 415 & $<0.0001$ \\
A $\times$ B & 6 & 1445 & 42 & $<0.0001$ \\
Error & 14 & 80 & & \\
Non-polar & & & & \\
Filmed/non-filmed (A) & 1 & 345 & 84 & $<0.0001$ \\
Tube type (B) & 6 & 2159 & 88 & $<0.0001$ \\
A $\times$ B & 6 & 786 & 32 & $<0.0001$ \\
Error & 14 & 57 & & \\
& & & & \\
\hline
\end{tabular}

tween the number of settled larvae and the contact angle of filmed tubes (Table 3). Since larvae of this species do not settle well on surfaces without biofilm (Beckman et al. 1999), we concluded that larval settlement of $H$. elegans does not respond to contact angles of filmed tubes in field conditions. Overall, $H$. elegans only settled at very low flow rates and within a very narrow flow regime. No larvae settled in the tubes when the flow rates were at or above $12.7 \mathrm{~cm} \mathrm{~s}^{-1}$.

Larval settlement of Hydroides elegans in the laboratory experiments (Fig. 2B) differed from that observed in the field experiments, although it was also affected by both flow rates and type of drop) (Fig. 1). This decrease might have been due to the leaching of dibutyl tin to the surface. The resulting contact angles could be arranged as follows: Teflon $>$ PVC $2>$ PU $>$ PE $>$ PVC3 $=$ PVC1 > Glass (1-way ANOVA, $F_{6,34}=147.3$, p < 0.0001) (Fig. 1). For non-polar conditions, the contact angles of filmed tubes increased significantly, except in the case of glass tubes, for which the contact angles decreased in both the polar and non-polar conditions when the tubes were filmed. The resulting contact angles could be arranged as follows for non-polar conditions with filmed tubes: Teflon $>$ PVC $3=$ PVC $2>$ PE $>$ PVC $1>$ PU > Glass (1-way ANOVA, $F_{6,34}=$ 67.7, p < 0.0001) (Fig. 1). Overall, Teflon tubes had the largest contact angles, while glass tubes had the smallest.

\section{Larval settlement in response to flow rate in different types of tubes}

\section{Hydroides elegans}

Larval settlement of Hydroides elegans was significantly affected by both flow rates and type of tubes in the field experiment but with strong interaction between the effects of flow rates and types of the tubes (Fig. 2A). Larval settlement decreased with increases in flow velocity for all tube types, except for the glass tube, in which the number of settled larvae increased slightly, reaching their largest number at the flow rate of $2.1 \mathrm{~cm} \mathrm{~s}^{-1}$ and then decreased rapidly (Fig. 2A). Among the 7 types of tubes, at a given flow rate, larval settlement was almost always the highest in the Teflon tube, second highest in the PVC3 or PVC2 as well as the glass tube, and lowest in the PU and PE or PVC 1 tubes (Table 2). There was no correlation be-
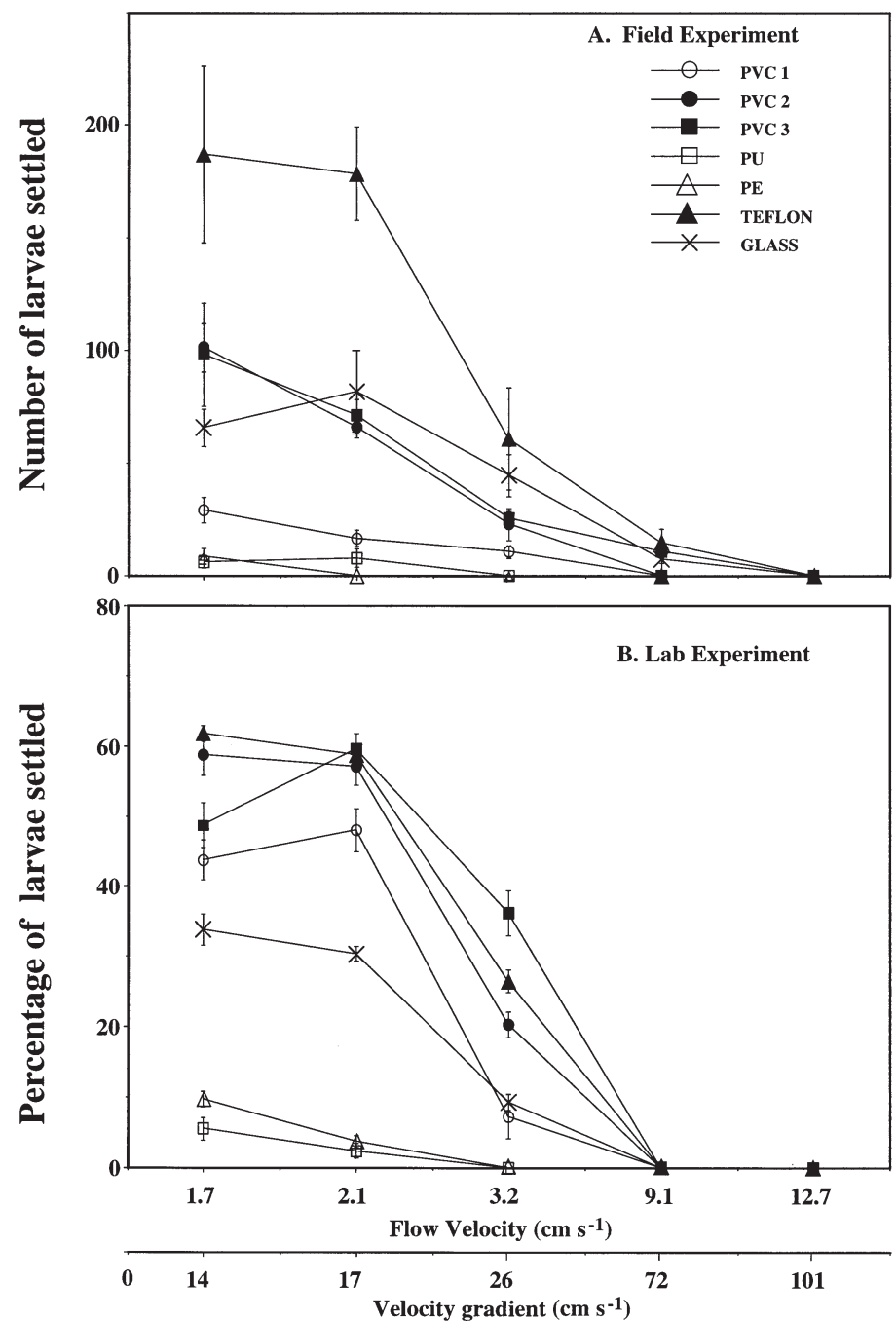

Fig. 2. Settlement of Hydroides elegans in 7 types of $10 \mathrm{~mm}$ diameter tubes: (A) in the field and (B) in the laboratory. Mean percentage of settlement or mean number of larvae settled \pm SD is plotted against mean flow velocity and mean velocity gradient. The velocity gradient was calculated according to Crisp (1955) and Qian et al. (1999), and was rounded up to the nearest integrate number 
tubes, and the 2 factors interacted strongly (Fig. 2B, Table 2). In both the PVC3 and PVC1 tubes, larval settlement first increased with flow rate and then dropped rapidly, while the larval settlement in other types of tubes dropped with increased flow rate. Larval settlement was the highest in the PVC3, Teflon or PVC2 tubes, and lowest in the PU and PE tubes (Fig. 2B, Table 2). Finally, larval settlement in the glass tube was higher than that in either the PE or PU tubes. In addition, the range of flow rates for larval settlement was narrower in the laboratory experiments, since no larvae settled in any types of tubes when flow velocities were at or above $9.1 \mathrm{~cm} \mathrm{~s}^{-1}$ (Fig. 2B). There was no correlation between the percentage of settled larvae and the contact angle of filmed tubes at any flow rate (Table 3).
Table 2. Summary of the results of the non-parametric Kruskal-Wallis test and nonparametric multiple comparison test (Zar 1999) on effects of types of tubes on larval settlement of Hydroides elegans, Bugula neritina and Balanus spp., in both field and laboratory experiments. Values not differing at 0.05 level are joined by underlining.

Values of all parameters are shown inascending rank order from left to right

\begin{tabular}{|c|c|c|c|c|}
\hline Expt & $\begin{array}{l}\text { Flow rate } \\
\left(\mathrm{cm} \mathrm{s}^{-1}\right)\end{array}$ & $H$ & $\mathrm{p}$ & Tube types \\
\hline \multicolumn{5}{|c|}{ H. elegans } \\
\hline \multirow[t]{5}{*}{ Field } & 1.7 & 18.5 & $<0.01$ & $\underline{\text { PU PE PVC1 Glass PVC3 PVC2 Teflon }}$ \\
\hline & 2.1 & 18.3 & $<0.01$ & 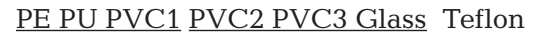 \\
\hline & 3.2 & 17.9 & $<0.01$ & $\underline{\text { PE PU PVC1 Glass PVC3 PVC2 Teflon }}$ \\
\hline & 9.1 & 15.1 & $<0.05$ & $\underline{\text { PU PVC2 PE PVC1 Glass }} \underline{\text { PVC3 Teflon }}$ \\
\hline & 12.7 & \multicolumn{2}{|c|}{ No settlement } & \\
\hline \multirow[t]{5}{*}{ Lab. } & 1.7 & 17.8 & $<0.01$ & $\underline{\text { PU PE Glass }} \underline{\text { PVC1 PVC3 }} \underline{\text { PVC2 Teflon }}$ \\
\hline & 2.1 & 19.2 & $<0.01$ & PU PE Glass PVC1 PVC2 Teflon PVC3 \\
\hline & 3.2 & 19.0 & $<0.01$ & PE PU PVC1 Glass PVC2 Teflon PVC3 \\
\hline & 9.1 & \multicolumn{2}{|c|}{ No settlement } & \\
\hline & 12.7 & \multicolumn{2}{|c|}{ No settlement } & \\
\hline \multicolumn{5}{|c|}{ B. neritina } \\
\hline \multirow[t]{7}{*}{ Field } & 1.7 & 18.4 & $<0.01$ & 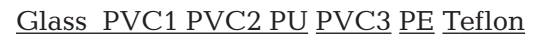 \\
\hline & 8.5 & 18.7 & $<0.01$ & Glass PVC1 PVC2 PU PE PVC3 Teflon \\
\hline & 12.7 & 18.0 & $<0.01$ & $\underline{\text { Glass PU PVC2 PVC1 }} \underline{\text { PE PVC3 }}$ Teflon \\
\hline & 21.2 & 18.1 & $<0.01$ & 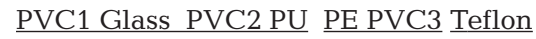 \\
\hline & 42.5 & 15.8 & $<0.05$ & PVC1 PVC2 Glass PU PE PVC3 Teflon \\
\hline & 53.0 & 12.3 & $>0.05$ & $\underline{\text { PVC1 PVC2 PE Glass PU Teflon PVC3 }}$ \\
\hline & 74.9 & \multicolumn{2}{|c|}{ No settlement } & \\
\hline \multirow[t]{7}{*}{ Lab. } & 1.7 & 18.8 & $<0.01$ & 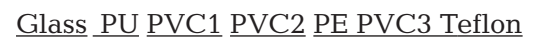 \\
\hline & 8.5 & 18.7 & $<0.01$ & $\underline{\text { Glass }} \underline{\text { PVC1 }} \underline{\text { PU PVC2 }} \underline{\text { PVC3 PE Teflon }}$ \\
\hline & 12.7 & 18.9 & $<0.01$ & Glass PU PVC1 PVC2 PVC3 PE Teflon \\
\hline & 21.2 & 17.9 & $<0.01$ & $\underline{\text { PU PVC1 Glass }} \underline{\text { PVC2 }} \underline{\text { PVC3 PE Teflon }}$ \\
\hline & 31.9 & 17.8 & $<0.01$ & 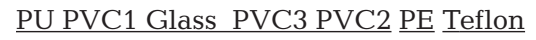 \\
\hline & 42.5 & \multirow{2}{*}{\multicolumn{2}{|c|}{$\begin{array}{l}\text { No settlement } \\
\text { No settlement }\end{array}$}} & \\
\hline & 53.0 & & & \\
\hline \multicolumn{5}{|c|}{ Balanus spp. } \\
\hline \multirow[t]{6}{*}{ Field } & 2.1 & \multicolumn{2}{|c|}{ No settlement } & \\
\hline & 4.2 & 15.6 & $<0.05$ & $\underline{\text { PE Teflon PU PVC3 PVC2 PVC1 Glass }}$ \\
\hline & 7.4 & 12.8 & $<0.05$ & Teflon PVC3 PE PU PVC2 PVC1 Glass \\
\hline & 10.6 & 17.8 & $<0.01$ & Teflon PVC3 PE PU PVC1 PVC2 Glass \\
\hline & 21.2 & 17.1 & $<0.01$ & Teflon PU PE PVC3 PVC1 PVC2 Glass \\
\hline & 31.9 & \multicolumn{2}{|c|}{ No settlement } & \\
\hline \multicolumn{5}{|c|}{ Balanus amphitrite } \\
\hline \multirow[t]{6}{*}{ Lab. } & 2.1 & \multirow{2}{*}{\multicolumn{2}{|c|}{$\begin{array}{l}\text { No settlement } \\
\text { No settlement }\end{array}$}} & \\
\hline & 4.2 & & & \\
\hline & 7.4 & 15.5 & $<0.05$ & Teflon PVC3 PE PU PVC2 $\underline{\text { PVC1 Glass }}$ \\
\hline & 10.6 & 17.7 & $<0.01$ & $\underline{\text { Teflon PE PU PVC3 }} \underline{\text { PVC1 PVC2 }} \underline{\text { Glass }}$ \\
\hline & 21.2 & 15.8 & $<0.05$ & Teflon PVC3 PU PE PVC1 PVC2 Glass \\
\hline & 31.9 & No s & ement & \\
\hline
\end{tabular}

\section{Bugula neritina}

Larval settlement of Bugula neritina was significantly affected by both flow rates and type of tubes in the field experiment, but with strong interaction between the 2 factors (Fig. 3A, Table 2). Larval settlement of $B$. neritina decreased with increases in flow velocity for all tube types (Fig. 3A). At all the flow rates, larval settlement was the highest in the Teflon tube, second highest in the PVC3 and PE tubes, and lowest, but similar, in the other types of tubes (Table 2). At all the flow rates, there was a positive correlation between the number of settled larvae and the contact angle of filmed tubes (please see rho- and p-values in Table 3). We concluded that the contact angle of the tubes affects the larval settlement of this species.

The same trend was found in the laboratory experiment (Fig. 3B, Tables $2 \& 3$ ). There was no larval settlement in any type of tube when flow velocity reached $42.5 \mathrm{~cm} \mathrm{~s}^{-1}$. In comparison, few larvae settled even at a flow rate of $53.0 \mathrm{~cm} \mathrm{~s}^{-1}$ in the field experiment.

\section{Balanus spp.}

Larval settlement of Balanus spp. was significantly affected by both flow rates and type of tubes in the field experiment, but with strong interaction between the 2 factors (Fig. 4A, Table 2). In the glass, PVC1 and PVC2 tubes, larval settlement of Balanus spp. first 
increased with flow, reached its highest level at a flow rate of $10.6 \mathrm{~cm} \mathrm{~s}^{-1}$, and then decreased with a further increase in a flow rate (Fig. 4A). The same trends were observed for the PU and PE tubes. In the Teflon and PVC3 tubes, however, the highest settlement was recorded at a flow rate of $4.2 \mathrm{~cm} \mathrm{~s}^{-1}$. Overall, attachment was the highest in the glass, PVC1 and PVC2 tubes and, in general, the lowest in the Teflon tubes. However, due to the large variations observed within each tube type, the non-parametric multiple comparison tests failed to separate the other 6 types of tubes, except glass, at most of the flow rates tested (Table 2). At all the flow rates, there was a negative correlation between the percentage of settled larvae and the con-
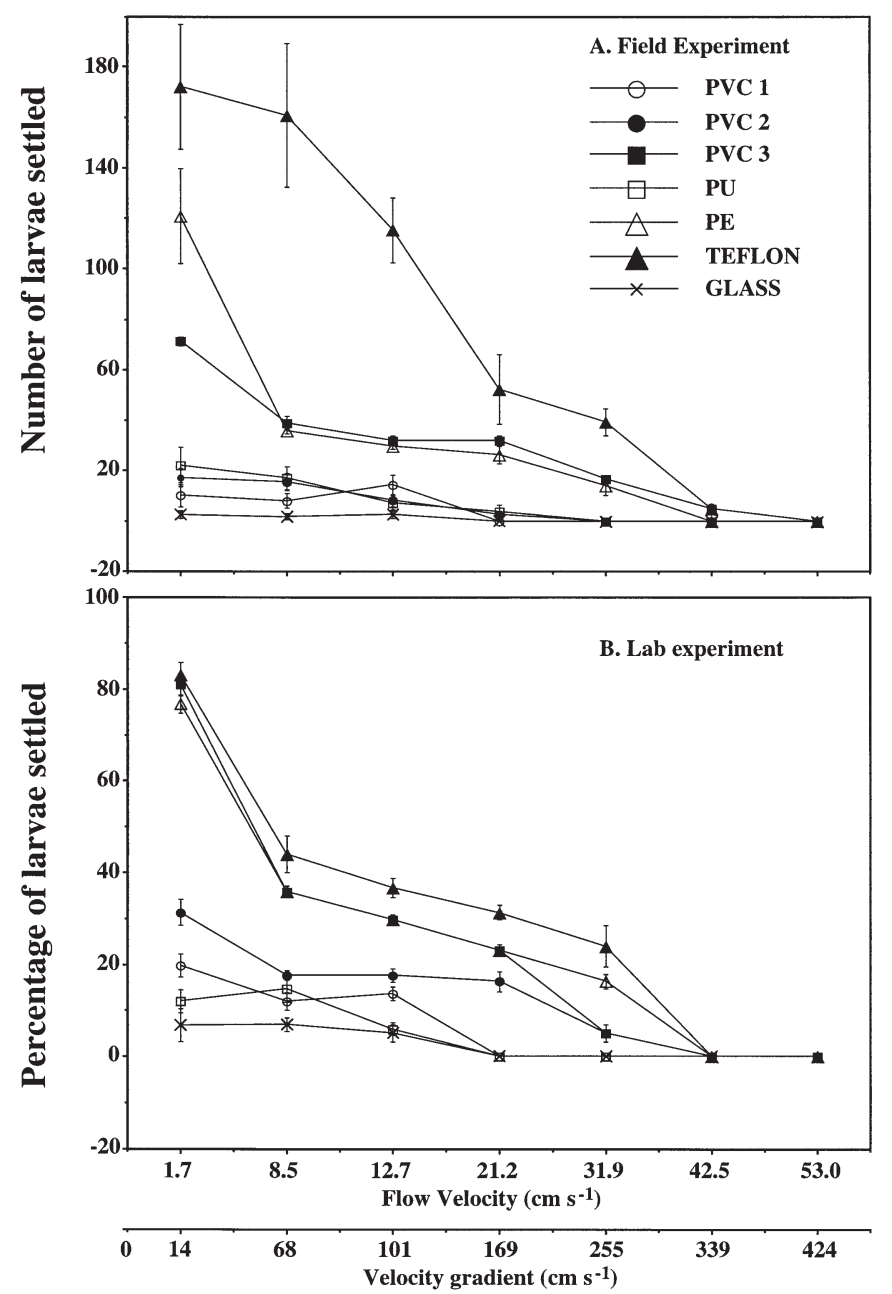

Fig. 3. Settlement of Bugula neritina in 7 types of $10 \mathrm{~mm}$ diameter tubes: (A) in the field and (B) in the laboratory. Mean percentage of settlement or mean number of larvae settled \pm SD is plotted against mean flow velocity and mean velocity gradient. The velocity gradient was calculated according to Crisp (1955) and Qian et al. (1999), and was rounded up to the nearest integrate number tact angle of filmed tubes (please see rho- and p-values in Table 3), indicating that Balanus spp. settled mostly on materials with relatively small contact angles.

Table 3. Summary of Spearman's rank correlation coefficient between contact angles of 7 types of tubes under polar condition and larval settlement. For Hydroides elegans, the correlation between contact angles of filmed tubes and larval settlement was calculated for both the laboratory and field experiments; for both Bugula neritina and Balanus spp., the correlation between contact angles of filmed tubes and larval settlement was calculated for the field experiment, but the correlation between contact angles of unfilmed tubes and larval settlement was calculated for the laboratory experiments.

For each test, $\mathrm{df}=20$

\begin{tabular}{|c|c|c|c|c|}
\hline Expt & $\begin{array}{c}\text { Flow rate } \\
\left(\mathrm{cm} \mathrm{s}^{-1}\right)\end{array}$ & Rho & $Z$ & $\mathrm{p}$ \\
\hline \multicolumn{5}{|c|}{ H. elegans } \\
\hline \multirow[t]{5}{*}{ Field } & 1.7 & 0.34 & 1.51 & 0.13 \\
\hline & 2.1 & 0.20 & 0.91 & 0.36 \\
\hline & 3.2 & 0.04 & 0.18 & 0.86 \\
\hline & 9.1 & 0.085 & 0.38 & 0.71 \\
\hline & 12.7 & \multicolumn{2}{|c|}{ No settlement } & \\
\hline \multirow[t]{5}{*}{ Lab. } & 1.7 & 0.42 & 1.86 & 0.060 \\
\hline & 2.1 & 0.28 & 1.24 & 0.21 \\
\hline & 3.2 & 0.19 & 0.85 & 0.40 \\
\hline & 9.1 & \multicolumn{2}{|c|}{ No settlement } & \\
\hline & 12.7 & \multicolumn{2}{|c|}{ No settlement } & \\
\hline \multicolumn{5}{|c|}{ B. neritina } \\
\hline \multirow[t]{7}{*}{ Field } & 1.7 & 0.63 & 2.83 & 0.0046 \\
\hline & 8.5 & 0.63 & 2.83 & 0.0046 \\
\hline & 12.7 & 0.43 & 1.94 & 0.052 \\
\hline & 21.2 & 0.61 & 2.74 & 0.0062 \\
\hline & 42.5 & 0.47 & 2.09 & 0.037 \\
\hline & 53.0 & 0.42 & 1.88 & 0.060 \\
\hline & 74.9 & \multicolumn{2}{|c|}{ No settlement } & \\
\hline \multirow[t]{6}{*}{ Lab. } & 1.7 & 0.69 & 3.09 & 0.002 \\
\hline & 8.5 & 0.78 & 3.48 & 0.0005 \\
\hline & 12.7 & 0.64 & 2.88 & 0.0039 \\
\hline & 21.2 & 0.70 & 3.13 & 0.0017 \\
\hline & 31.9 & 0.60 & 2.66 & 0.0078 \\
\hline & 53.0 & \multicolumn{2}{|c|}{ No settlement } & \\
\hline \multicolumn{5}{|c|}{ Balanus spp. } \\
\hline \multirow[t]{6}{*}{ Field } & 2.1 & \multicolumn{2}{|c|}{ No settlement } & \\
\hline & 4.2 & -0.53 & -2.24 & 0.017 \\
\hline & 7.4 & -0.50 & -2.24 & 0.025 \\
\hline & 10.6 & -0.51 & -1.29 & 0.022 \\
\hline & 21.2 & -0.55 & -2.48 & 0.013 \\
\hline & 31.9 & \multicolumn{2}{|c|}{ No settlement } & \\
\hline \multicolumn{5}{|c|}{ Balanus amphitrite } \\
\hline \multirow[t]{6}{*}{ Lab. } & 2.1 & \multicolumn{2}{|c|}{ No settlement } & \\
\hline & 4.2 & \multicolumn{2}{|c|}{ No settlement } & \\
\hline & 7.4 & -0.76 & -3.38 & 0.0007 \\
\hline & 10.6 & -0.78 & -3.49 & 0.0005 \\
\hline & 21.2 & -0.58 & -2.60 & 0.0093 \\
\hline & 31.9 & \multicolumn{2}{|c|}{ No settlement } & \\
\hline
\end{tabular}




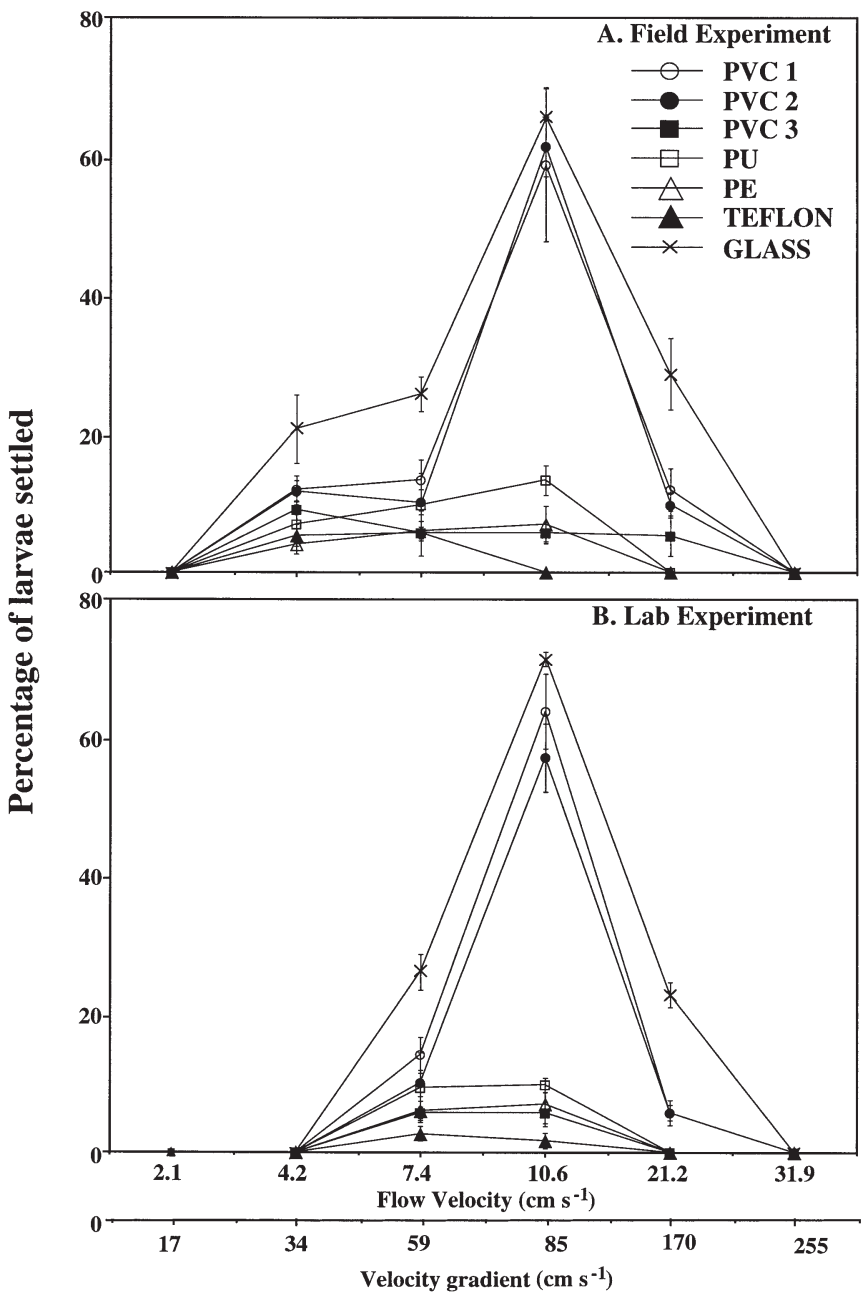

Fig. 4. Settlement of barnacle larvae in 7 types of tubes: (A) Balanus spp. in the field and (B) Balanus amphitrite in the laboratory. Mean percentage of settlement $\pm \mathrm{SD}$ is plotted against mean flow velocity and mean velocity gradient. The velocity gradient was calculated according to Crisp (1955) and Qian et al. (1999), and was rounded up to the nearest integrate number

Larval settlement of Balanus amphitrite was significantly affected by both flow rates and type of tubes in the laboratory experiment, but with strong interaction between the 2 factors (Fig. 4B, Table 2). Trends in barnacle attachment in the laboratory experiments were much clearer than those in the field experiments (Fig. 4B). The 7 types of tubes could be separated into 2 distinct groups. In the glass, PVC1 and PVC2 tubes, larval settlement first increased with flow, reached the highest level at a flow rate of $10.6 \mathrm{~cm} \mathrm{~s}^{-1}$, and then decreased with a further increase in flow rate. Larvae settled in flow rates ranging from 4.2 to $21.2 \mathrm{~cm} \mathrm{~s}^{-1}$. In the other 4 types of tubes, larval settlement increased with flow, reached the highest level at a flow rate of $7.4 \mathrm{~cm} \mathrm{~s}^{-1}$, and then dropped to 0 at a flow rate of
$21.2 \mathrm{~cm} \mathrm{~s}^{-1}$. Overall, the glass tube had the highest attachment at any given flow rate, the PVC1 and/or PVC2 tubes had the second highest, whereas the Teflon tube had the lowest (Table 2). At all the flow rates, again, there was a negative correlation between the number of settled larvae and the contact angle of unfilmed tubes (Table 3).

\section{Bacterial density on the inner walls of the 7 types of tubes}

The effect of tube type on bacterial density was highly significant (1-way ANOVA: $F_{6,29}=75.2$, p < 0.0001) (Fig. 5). The Tukey- $B$ multiple comparison test indicated that the bacterial density on the walls of the PVC1 tube was the highest, and those on the walls of the PVC2 and PVC3 tubes were the second highest, yet similar. The bacterial density on the PE tube walls was the third highest, while those on the walls of the glass and Teflon tubes were the lowest.

\section{Comparisons of the responses of Balanus spp., Hydroides elegans and Bugula neritina to different flow rates}

Larvae of the 3 organisms responded differently to the flow conditions presented. Bugula neritina settled maximally in low flow conditions but settled over a wide range of flows, while Hydroides elegans settled maximally in very low flow conditions and settled over a relatively narrow range of flows. Both $H$. elegans and $B$. neritina larvae settled maximally at a velocity of 1.7 to $2.1 \mathrm{~cm} \mathrm{~s}^{-1}$. In contrast, Balanus spp. larvae settled over a relatively narrow range of higher flow rates, and maximally at a flow rate of $10.6 \mathrm{~cm} \mathrm{~s}^{-1}$ (5 to 10 times higher than the optimal rates for the other 2 species).

\section{Comparisons of the responses of Balanus spp., Hydroides elegans and Bugula neritina to different types of tubes}

Larval settlement of the 3 organisms in the 7 types of tubes was significantly different. Balanus spp. larvae showed the highest settling rate on the glass tube but the lowest settling rate on the Teflon tube. This trend was very consistent at all flows tested in the field experiments regardless of whether the tubes were filmed or not (Table 3). In comparison, there was no correlation between the type of tubes and larval settlement in Hydroides elegans, while there was a very good correlation in Bugula neritina, which had the highest settling rate on the Teflon tube (see Table 3). 


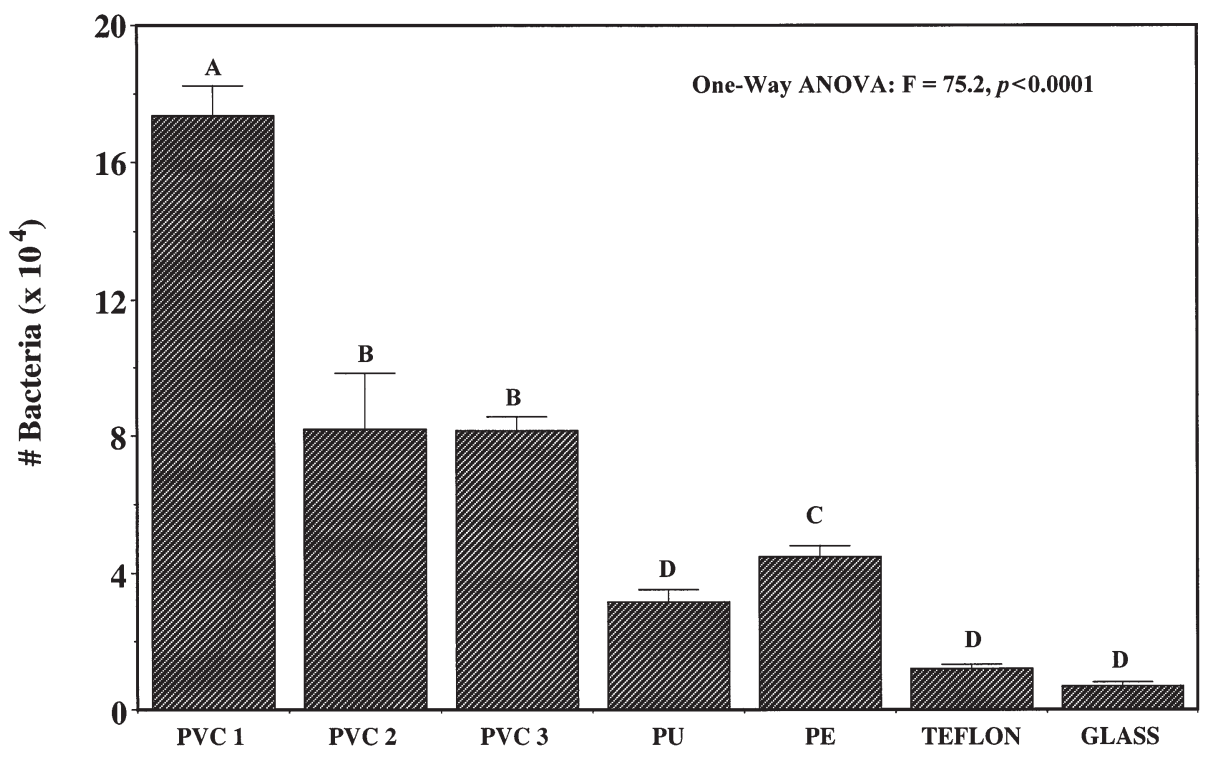

Fig. 5. Bacterial density on inner walls of 7 types of $10 \mathrm{~mm}$ diameter tubes developed in the laboratory over $48 \mathrm{~h}$. Mean density $\pm \mathrm{SD}$ is plotted. Different letters above the bars indicate data with significant differences

\section{DISCUSSION}

In the laboratory and field experiments, with very little variation, there were consistent negative correlations between larval settlement of barnacles and contact angles of tubes, regardless of the flow rates or of the filmed or unfilmed tubes (Table 3), indicating that barnacle larvae preferentially settled on the materials with smaller contact angles, such as glass tubes. Materials, such as Teflon tube, that have larger contact angles were clearly less attractive to barnacle larvae. In comparison, there were rather consistent positive correlations between larval settlement of Bugula neritina and contact angle of tubes (either filmed or unfilmed), also regardless of the flow rates (Table 3), indicating that larvae of this species preferred to settle on the materials with large contact angles. B. neritina larvae showed the highest settlement in Teflon tube and the lowest in glass tube (Fig. 3, Tables 2 \& 3). Although Hydroides elegans larvae also showed the highest settlement in Teflon tube, there was no correlation between larval settlement of $H$. elegans and contact angles of tube materials (Fig. 2, Tables $2 \& 3$ ).

Why did the 3 species respond to tube materials with different contact angles differently? It has been well documented that films are a prerequisite for settlement of Hydroides elegans (Hadfield et al. 1994, Qian 1999, Qian et al. 1999). Larval settlement of $H$. elegans on glass slides increased linearly with microbial film of increasing age (Hadfield et al. 1994, Beckmann et al. 1999). Although numerous studies have addressed the effect of biofilms on surface properties (particularly in terms of strength of the adhesion of molecules) (Savage \& Fletcher 1985), the relationship between biofilms and the contact angles of different materials remains unclear. It is clear that the polarity of a surface will change with the nature and development of biofilm. H. elegans settles almost everywhere as long as the surface is filmed (see review by Qian 1999), indicating that biofilm rather than the contact angle of the surface plays an important role in larval settlement. In comparison, Bugula neritina larvae settled almost equally well on both filmed and unfilmed surfaces (see also Qian et al. 1999). All of the previous studies showed that the larvae of bryozoans such as $B$. neritina and Watersipora sp. preferred non-wettable substrata like wax and graphite (Eiben 1976, Maki et al. 1989). In the present study, we confirmed that larvae of $B$. neritina preferred to settle on the Teflon tube with the largest contact angle (low wettability), while only a few larvae settled on the glass tubes with the smallest contact angle (high wettability) (Fig. 3). Similarly, barnacle larvae do not require a biofilm for settlement, settle equally well on filmed or unfilmed tubes, and prefer to settle on glass tube (Qian et al. 1999). However, in contrast to bryozoan larvae, barnacles settled in greater numbers on substrata with small contact angles (high surface energy) (Rittschof \& Costlow 1989b, Roberts et al. 1991, Qian et al. 1999). In this study, we confirmed that barnacles responded similarly in a variety of unidirectional flow conditions and settled in the greatest numbers on glass tubes and in the smallest numbers on Teflon tubes, indicating that Balanus amphitrite settlement in consistent flow is sim- 
ilar to that in static conditions and in undefined flow (Fig. 4). Therefore, we conclude that different relationships between contact angle of tube materials and larval settlement among the 3 species are mainly due to the differences in their prerequisite for settlement.

The number of larvae settling in a pipe depends upon larval availability and the settlement responses to flow and surface type. Availability of planktonic larvae is directly related to the volume of water passing through the pipe. Thus, a flow of $2 \mathrm{~cm} \mathrm{~s}^{-1}$ would potentially deliver twice the number of larvae to a surface as a flow of $1 \mathrm{~cm} \mathrm{~s}^{-1}$. In this study, we reported the number of larvae settled for Hydroides elegans and Bugula neritina inside tubes for the field experiment without correcting for the total water volume flowing through the tubes. If the correction is made, it decreases relative settlement at high flow rates and increases the relative settlement at low flow rates. However, the general trends would be the same, which were demonstrated by the percentage of larvae settled inside tubes plotted in Figs. 2B, 3B \& 4.

Responses of Balanus spp. and Balanus amphitrite larvae to the flow in the field and laboratory experiments, respectively, show dramatic increases on wettable surfaces near an optimum flow of $10.6 \mathrm{~cm} \mathrm{~s}^{-1}$. These results complement those previously reported (Rittschof et al. 1984, Rittscof \& Costlow 1989a,b, Roberts et al. 1991, Qian et al. 1999) and confirmed further that barnacle larvae do not settle at very high flow. This settlement response to flow has been related to larval morphology and settling behavior (Crisp 1955). However, the optimal flow rates for Balanus spp. and Balanus amphitrite larval settlement differed from those reported in early studies for the barnacle Balanus (= Semibalanus) balanoides (Crisp 1955). S. balanoides larvae require higher velocities and hence settle in higher energy environments. S. balanoides have relatively large larvae and live on very high-energy, openocean, rocky shores, while the smaller Balanus spp. larvae such as $B$. improvisus and $B$. amphitrite usually occupy lower wave energy environments ( $\mathrm{O}^{\prime}$ Connor \& Richardson 1996).

Larval settlement of Bugula neritina decreased with increase in flow rate, which is in very good agreement with previous reports (Qian et al. 1999). Decrease in settling rate with increased flow rate may indicate that larval settlement in this species is a passive process. High flow rates reduce the larval contact with surface and lead to a low settling rate. However, the relatively broad range of velocities over which $B$. neritina settle on the tubes may also suggest that the ciliated surface of $B$. neritina may enable it to gain purchase on surfaces over a wide range of flows. This may explain why this species can settle in a broader range of flow than barnacle larvae and Hydroides elegans larvae. As shown in Fig. 3, although settlement of B. neritina was the highest at the lowest flow rate tested, some larvae settled at very high flow rates $\left(>50 \mathrm{~cm} \mathrm{~s}^{-1}\right)$.

Hydroides elegans, with the smallest larvae of the group, had the narrowest range of settlement in relation to flow rate. Its clear propensity to settle in only very low flows suggests that swimming capability is important. Based on our observations (Qian et al. 1999, present study), one may conclude that, for both $H$. elegans and Bugula neritina, flow is not a requirement of larval settlement. However, all of these species ( $H$. elegans, B. neritina and Balanus spp.) are found in cooling water intakes of the HKUST (Qian pers. obs.) with a continuous flow greater than $60 \mathrm{~cm} \mathrm{~s}^{-1}$. This suggests that there are locations in larger pipes where turbulence may carry larvae to a surface upon which they encounter low flow conditions favorable for attachment. Growth of initial colonizers would result in new areas of favorable settlement conditions. The virtual monoculture of $H$. elegans that recently clogged the cooling water intake of HKUST attests to the fact that larvae can colonize surfaces in flows far outside the range of their initial capability in unfouled pipes.

The ability of bacteria to attach to different types of tubes varied (Fig. 5). Bacteria did not attach well to tubes that had either the largest contact angles (Teflon tube) or the smallest contact angles (glass tubes). Although it has been suggested that both surface free energy and surface charge influence bacterial attachment (Fletcher \& Loeb 1979), in the present study, we found no correlation between bacterial density and contact angles of tubes. Poor correlation between contact angles and bacterial density could be caused by many parameters that were not monitored in this study. For instance, dissolved substances adsorbed by the substratum can modify the substratum's surface properties and, in turn, may play an important role in the attachment of bacteria (Neihoff \& Loeb 1972, Baier 1973). Furthermore, different marine bacteria may have different preferences toward surfaces with different contact angles (Fletcher \& Loeb 1979, Burchard et al. 1991). We did not study the composition of the microbial film and, thus, could not determine if there were differences in the species compositions of the biofilms found on different tube surfaces. Biofilm composition becomes increasingly complex with time and varies with the physical/chemical characteristics of the initial surface (Marszalek et al. 1979, Dempsey 1981). The composition of biofilm and its change over time, as well as its influence on larval settlement, are topics for future investigation.

It seems questionable whether our experimental design can permit full assessment of the settling process in the laboratory setup, since the tubes there were arranged vertically while those in the field experi- 
ments were arranged horizontally. This concern is mainly based on the effect of gravity on larval settlement. Previous studies have indicated that larvae respond to shear forces to find surfaces (see review by Crisp 1984), and gravity plays little if any role in settlement. As discussed above, we found that larvae of the 2 groups of organisms responded to contact angles of substratum in both the laboratory and field, indicating that an active selection process was involved in larval settlement. Settlement in experiments was independent of tube orientation, and, therefore, gravity may play at best a minor role in determining the settlement patterns.

In conclusion, this study showed that larval settlement of barnacles, bryozoans and polychaetes is influenced strongly by the chemical characteristics of the substratum, as well as the flow rate. If a larva can break through the boundary layer between substratum and overlying water, its settlement is dependent on the chemical characteristics. Therefore, physical and chemical properties of the substratum should be carefully considered in the design of surfaces that come into contact with seawater. However, after a short time, this becomes less important. For this reason, a tube made of material with either a large or small contact angle will predictably promote larval settlement of these major fouling organisms until the energy of the surface is altered by adsorption of organic matter and development of biofilms.

Acknowledgements. This research was supported by a UGC research infrastructure grant (1995/96) from the Hong Kong University of Science and Technology (HKUST) and a RGC grant (HKUST6133/99M) to P.Y.Q. Dr Ying Zhang helped in developing the field experiment apparatus in the early stage of the project. The authors also thank the anonymous reviewers and Larry McEdward for their comments on the manuscript and Virginia Unkefer of HKUST for proof-reading the manuscript.

\section{LITERATURE CITED}

Baier RE (1973) Influence of the initial surface condition of materials on bioadhesion. In: Proceedings of the 3rd Internation Congr Marine Corrosion and Fouling. Northwestern University Press, Evanston, IL, p 633-639

Baier RE (1982) Conditioning surfaces to suit the biomedical environment. J Biomech Eng 104:257-271

Baier RE (1984) Initial events in microbial film formation. In: Costlow JD, Tipper RC (eds) Marine biodeterioration: an interdisciplinary study. Naval Institute Press, Annapolis, MD, p 57-62

Becker K, Wahl M (1991) Influence of substratum surface tension on biofouling of artificial substrata in Kiel Bay (western Baltic): in situ studies. Biofouling 4:275-291

Beckmann M, Harder T, Qian PY (1999) Induction of larval attachment and metamorphosis in the serpulid polychaete Hydroides elegans (Haswell) by dissolved free amino acids. Part II. Mode of action in laboratory bioassays. Mar Ecol Prog Ser 190:167-178

Bryan JP, Qian PY, Kreider JL, Chia FS (1997) Chemical induction of settlement and metamorphosis of the serpulid polychaete Hydroides elegans. Mar Ecol Prog Ser 146: 81-90

Bryan JP, Kreider JL, Qian PY (1998) Settlement of the polychaete Hydroides elegans on surfaces of the chelistome bryozoan Bugula neritina: evidence for a chemically mediated relationship. J Exp Mar Biol Ecol 220:171-190

Burchard RP, Rittschof D, Bonaventura J (1991) Adhesion and motility of gliding bacteria substrata of different surface free energies. Appl Environ Microbiol 56:2529-2534

Butman CA (1986) Larval settlement of soft-sediment invertebrates: some predictions based on an analysis of near-bottom velocity profiles. In: Nihoul JCI (ed) Marine interfaces ecohydrodynamics. Elsevier, Amsterdam, p 487-514

Butman CA (1987) Larval settlement of soft-sediment invertebrates: the spatial scales of pattern explained by active habitat selection and the emerging role of hydrodynamical processes. Oceanogr Mar Biol Annu Rev 25:113-165

Crisp DJ (1955) The behaviour of barnacle cyprids in relation to water movement over a surface. J Exp Biol 32:569-590

Crisp DJ (1974) Factors influencing the settlement of marine interbrate larvae. In: Grant PT, Mackie AM (eds) Chemoreception in marine organisms. Academic Press, London, p $177-265$

Crisp DJ (1984) Overview of research on marine invertebrate larvae 1940-1980. In: Costlow JD, Tipper RC (eds) Marine biodeterioration: an interdisciplinary study. Naval Institute, Annapolis, MD, p 103-126

Dempsey MJ (1981) Colonization of antifouling paints by marine bacteria. Bot Mar 24:185-191

Eckman JE, Savidge WB, Gross TF (1990) Relationship between duration of cyprid attachment and drag forces associated with detachment of Balanus amphitrite cyprids. Mar Biol 107:111-118

Eiben R (1976) Einfluß von Benetzungsspannung und Ionen auf die substratbesiedlung und das Einsetzen der Metamorphose bei Bryozoenlarven (Bowerbankia gracilis). Mar Biol 37:249-254

Fletcher M, Loeb GI (1979) The influence of substratum characteristics on the attachment of a marine pseudonomad to solid surfaces. Appl Environ Microbiol 37:67-72

Gerhart DJ, Rittschof D, Hooper IR, Eisenman K, Meyer AE, Baier RE, Young C (1992) Rapid and inexpensive quantification of the combined polar components of surface wettability: application to biofouling. Biofouling 5:251-259

Hadfield MG, Unabia CC, Smith CM, Michael TM (1994) Settlement preferences of the ubiquitous fouler Hydroides elegans. In: Thompson MF, Nagabhushanam R, Sarojini R, Fingerman $M$ (eds) Recent developments in biofouling control. Balkema, Rotterdam, p 65-74

Harder T, Qian PY (1999) Amino acids as conspecific chemical signals for larval attachment and metamorphosis in the serpulid polychaete Hydroides elegans (Haswell). Mar Ecol Prog Ser 179:259-271

Holm ER, Cannon G, Roberts D, Schmidt AR, Sutherland JP, Rittschof D (1997) The influence of initial surface chemistry on the development of the fouling community at Beaufort, North Carolina. J Exp Mar Biol Ecol 215: $189-203$

Holmström C, Rittschof D, Kjelleberg S (1992) Inhibition of settlement by larvae of Balanus amphitrite and Ciona intestinalis by a surface-colonizing marine bacterium. Appl Environ Microbiol 58:2111-2115

Kirchman D, Graham S, Reish D, Mitchell R (1982a) Bacteria 
induce settlement and metamorphosis of Janua (Dexiospira) brasiliensis Grube (Polychaeta: Spirorbidae). J Exp Mar Biol Ecol 56:153-163

Kirchman D, Graham S, Reish D, Mitchell R (1982b) Lectins may mediate in the settlement and metamorphosis of Janua (Dexiospira) brasiliensis Grube (Polychaeta: Spirorbidae). Mar Biol Lett 3:131-142

Lau SCK, Qian PY (1997) Phlorotannis and related compounds as larval settlement inhibitors of a tube-building polychaete Hydroides elegans (Hawell). Mar Ecol Prog Ser 159:219-227

Maki JS, Rittschof D, Costlow JD, Mitchell R (1988) Inhibition of attachment of larval barnacles, Balanus amphitrite, by bacterial surface films. Mar Biol 97:199-206

Maki JS, Rittschof D, Schmidt AR, Snyder AG, Michell R (1989) Factors controlling attachment of bryozoan larvae; a comparison of bacterial films and unfilmed surfaces. Biol Bull 177:295-302

Maki JS, Rittschof D, Samuelsson MO, Szewzyk U, Yule AB, Kjelleberg B, Costlow JD, Mitchell R (1990) Effect of marine bacteria and their exopolymers on the attachment of barnacle cypris larvae. Bull Mar Sci 46:499-511

Maki JS, Rittschof D, Mitchell R (1992) Inhibition of larval barnacle attachment to bacterial films: an investigation of physical properties. Microb Ecol 23:97-106

Maki JS, Yule AB, Rittschof D, Mitchell R (1994) The effect of bacterial films on the temporary adhesion and permanent fixation of cypris larvae, Balanus amphitrite Darwin. Biofouling 8:121-131

Marszalek DS, Gerchako SM, Utey LR (1979) Influence of substrate composition on marine microfouling. Appl Environ Microbiol 38:987-995

Meyer AE, Baier RE, King RW (1988) Initial fouling of nontoxic coatings in fresh, brackish and seawater. Can J Chem Eng 66:55-62

Mullineaux LS, Garland ED (1993) Larval recruitment in response to manipulated field flows. Mar Biol 116:667-683

Neihof RA, Loeb GI (1972) The surface charge of particulate matter in seawater. Limnol Oceanogr 17:7-16

O'Connor NJ, Richardson DL (1996) Comparative attachment of barnacle cyprids (Balanus iimprovisus Darwin) larvae: laboratory and field studies. J Exp Mar Biol Ecol 206: 69-81

Olivier F, Tremblay R, Bourget E, Rittschof D (2000) Barnacle settlement: field experiments on the influence of larval supply, tidal level, biofilm quality and age on Balanus amphitrite cyprids. Mar Ecol Prog Ser 199:185-204

Pawlik JR (1992) Induction of marine invertebrate larval settlement: evidence for chemical cues. In: Paul VJ (ed) Ecological roles of marine natural products. Cornell University Press, Ithaca, NY, p 189-235

Pawlik JR, Butman CA, Starczak VR (1991) Hydrodynamic facilitation of gregarious settlement of a reef-building tube worm. Science 251:421-424

Pechenik JA, Qian PY (1998) Onset and maintenance of metamorphic competence in the marine polychaete Hydroides elegans Haswell in response to three chemical cues. J Exp Mar Biol Ecol 226:51-74

Qian PY (1999) Larval settlement of polychaetes. Hydrobiologia 402:239-253

Qian PY, Pechenik JA (1998) Effects of delayed metamorphosis and starvation on postmetamorphic growth and survival of the tube-dwelling polychaete Hydroides elegans. J Exp Mar Biol Ecol 227:169-185

Qian PY, Rittschof D, Sreedhar B, Chia FS (1999) Effects of flow velocity on larval settlement of macrofouling organ- isms inside pipes with unidirectional flows of coastal seawater. Mar Ecol Prog Ser 191:141-151

Qiu JW, Qian PY (1997a) Combined effects of salinity, temperature and food concentration on early development of the polychaete Hydroides elegans (Haswell, 1883). Mar Ecol Prog Ser 152:79-88

Qiu JW, Qian PY (1997b) Effects of food availability, larval source and culture method on larval development of Balanus amphitrite amphitrite Darwin: implications for experimental design. J Exp Mar Biol Ecol 217:47-61

Qiu JW, Gosselin LA, Qian PY (1997) Effects of short-term variation in food availability on larval development in the barnacle Balanus amphitrite. Mar Ecol Prog Ser 161:83-91

Rittschof D, Costlow JD (1989a) Surface determination of macroinvertebrate larval settlement. In: Styczynsk-Jurewicz E (ed) Proc 21st Eur Mar Biol Symp. Polish Academy of Sciences, Institute of Oceanology, Gdansk, p 155-163

Rittschof D, Costlow JD (1989b) Bryozoan and barnacle settlement in relation to initial surface wettability: a comparison of laboratory and field studies. In: Ros JD (ed) Topics in marine biology, Proc 22nd Eur Mar Biol Symp. Instituto de Ciencias del Mar, Barcelona, p 411-416

Rittschof D, Branscomb ES, Costlow JD (1984) Settlement and behaviour in relation to flow and surface in larval barnacles, Balanus amphitrite Darwin. J Exp Mar Biol Ecol 82: 131-146

Rittschof D, Hooper IRH, Costlow JD (1988) Settlement inhibition of marine invertebrate larvae: comparison of sensitivities of bryozoan and barnacle larvae. In: Thompson M, Sarojini R, Nagabhushanam R (eds) Marine biodeterioration. Oxford and IBW, Bombay, p 599-608

Rittschof D, Forward RB Jr, Cannon G, Welch JM, McClary M Jr, Holm ER, Clare AS, Conova S, McKelvey LM, Bryan P, van Dover CL (1998) Cues and context: larval responses to physical and chemical cues. Biofouling 12:31-44

Roberts D, Rittschof D, Holm E, Schmidt AR (1991) Factors influencing larval settlement: temporal, spatial and molecular components of initial colonization. J Exp Mar Biol Ecol 150:203-222

Savage DC, Fletcher M (1985) Bacterial adhesion: mechanisms and physiological significance. Plenum Press, New York

Turley CM (1993) Direct estimates of bacterial numbers in seawater samples without incurring cell loss due to sample storage. In: Kemp PF, Sherr BF, Sherr EB, Cole JJ (eds) Handbook of methods in aquatic microbial ecology. Lewis Publishers, Boca Raton, p 143-147

Vrolijk NH, Targett NM, Baier RE, Meyer AE (1990) Surface characterisation of two gorgonian coral species: implications for a natural antifouling defence. Biofouling 2:39-45

Walters LJ (1992a) Post settlement success of the arborescent bryozoan Bugula neritina (L): the importance of structural complexity. J Exp Mar Biol Ecol 164:55-71

Walters LJ (1992b) Field settlement location on subtidal marine hard substrata: is active larval exploration involved? Limnol Oceanogr 37:1101-1107

Walters LJ, Hadfield MG, del Carmen KA (1997) The importance of larval choice and hydrodynamics in creating aggregations of Hydroides elegans (Polychaeta: Serpulidae). Invertebr Biol 116:102-114

Wethey D (1986) Ranking of settlement cues by barnacle larvae: influence of surface contour. Bull Mar Sci 39:392-400

Young T (1805) An essay on the cohesion of fluids. Phil Trans R Soc Lond 95:65-87

Zar JH (1999) Biostatistical analysis, 3rd edn. Prentice Hall Inc, Upper Saddle River, NJ 